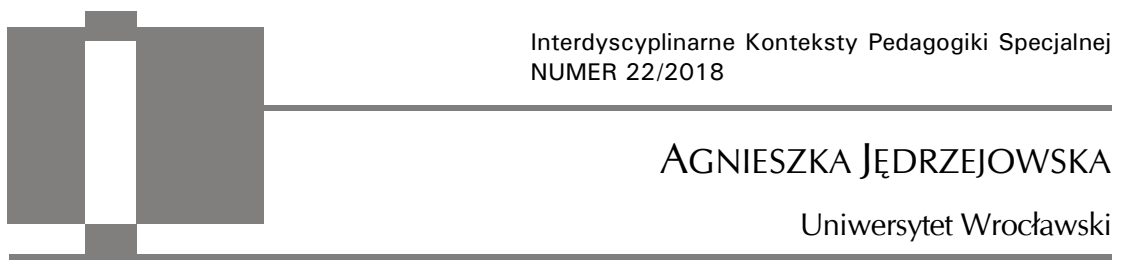

\title{
Umiejętności komunikacyjne dzieci z zespołem Downa ${ }^{1}$
}

\begin{abstract}
Agnieszka Jędrzejowska, Umiejętności komunikacyjne dzieci z zespotem Downa [Communication skills of children with Down Syndrome]. Interdyscyplinarne Konteksty Pedagogiki Specjalnej, nr 22, Poznań 2018. Pp. 201-218. Adam Mickiewicz University Press. ISSN 2300-391X. DOI: https:// doi.org/10.14746/ikps.2018.22.12

The purpose of this article is to present the results of research concern setting of functional cooperation with the interlocutor in children with Down syndrome in a peer group. Analysis of the results indicates the relationship between methods of therapy and development of children with Down syndrome. The methods of Alterantive and Augmentative Communication (AAC) are important in achieving success in building relationships for children with problems with verbal communication. Secondly, peer group is important to increase social skills. This research show that children with Downe syndrome need similar friends. This leads to the coclussion that group with homogeneous disability is area of development.
\end{abstract}

KEY WORDS: communication skills, peer grup, Down syndrome, alternative and augmentative communiaction (AAC)

Stosunek do osób z niepełnosprawnością zmienił się w ciągu ostatniego stulecia. Zarówno deinstytucjonalizacja, jak i integracja

${ }^{1} \mathrm{~W}$ tekście zaprezentowane zostały wybrane wyniki badań z pracy doktorskiej, opublikowane $\mathrm{w}$ monografii pt. Wspomaganie rozwoju spotecznego dziecka z zespotęm Downa w przedszkolnej grupie rówieśniczej, Oficyna Wydawnicza Atut - Wrocławskie Wydawnictwa Oświatowe, Wrocław 2017. 
oraz normalizacja spowodowały, że coraz więcej osób z niepełnosprawnością mogło zmienić własne położenie społeczne. W miejsce bezradności i izolacji pojawiły się nadzieja, poczucie mocy, aktywność, spełnienie, sens życia.

Zmiana $\mathrm{w}$ postawie względem osób $\mathrm{z}$ trudnościami $\mathrm{w}$ rozwoju wyznaczyła nowy kierunek wsparcia, który chciałabym przedstawić na przykładzie badań prowadzonych wśród dzieci z zespołem Downa (w dalszej części tekstu będę posługiwać się skrótem ZD). Małgorzata Skórczyńska zauważa, że w ostatnim czasie kładzie się większy nacisk na wspomaganie rozwoju dzieci z tym zaburzeniem rozwojowym poprzez zachęcanie ich do aktywności, w których mogą wykorzystać swoje umiejętności i zalety². Jednak pewne specyficzne cechy towarzyszące ich rozwojowi zawsze będą determinować odnoszone sukcesy czy niepowodzenia. W związku z tym potrzeby edukacyjne tych dzieci, rozumiane jako potrzeby uczenia się, są realizowane $\mathrm{z}$ uwzględnieniem indywidualnych możliwości, $\mathrm{w}$ tym utrudnień i blokad występujących w rozwoju, które determinują sposób i warunki realizacji potrzeb. Nie stanowi to jednak podstaw do wydzielenia spośród wszystkich potrzeb dziecka specjalnych potrzeb edukacyjnych. U dzieci z ZD są one takie same jak $\mathrm{u}$ ich pełnosprawnych rówieśników. Zaspokojenie i realizacja tych potrzeb wymaga czasem dostosowania sposobu działań pedagogicznych do różnego stopnia rozwoju dzieci. Wincenty Okoń podkreśla, że celem takiego postępowania jest zapewnienie maksymalnych możliwości rozwoju dzieciom o różnych zdolnościach ${ }^{3}$.

Specyficzne cechy wpływające na zdolność dzieci z ZD do uczestnictwa w kontakcie z drugim człowiekiem, a także do uczenia się, mają różne nasilenie u poszczególnych jednostek. Należy do nich hipotonia, czyli słabe napięcie mięśniowe, które wpływa na sprawność manualną i motoryczną. Tu od razu jako konsekwencję

${ }^{2}$ M. Skórczyńska, Wspomaganie rozwoju dziecka z zespołem Downa w wieku przedszkolnym, [w:] Wczesna interwencja i wspomaganie rozwoju małego dziecka, red. B. Сytowska, B. Winczura, Oficyna Wydawnicza „Impuls”, Kraków 2008, s. 345.

3 W. Okoń, Nowy stownik pedagogiczny, Żak Wydawnictwo Akademickie, Warszawa 1998 , s. 134. 
dostrzec można osłabiony udział $\mathrm{w}$ zabawach ruchowych, które stanowią jedną z podstawowych aktywności dzieci. Kolejnymi cechami mogącymi wpływać na funkcjonowanie dzieci wśród innych dzieci, są: obniżona sprawność aparatu mowy, problemy z mową i językiem, wolniejsze tempo rozwoju słownictwa ekspresyjnego oraz deficyty leksykalne i syntaktyczne. Monika Niklasińska badała, w jaki sposób zdrowe dzieci postrzegają swoich niepełnosprawnych kolegów z przedszkola. Dowiodła, że dla pełnosprawnych przedszkolaków gotowość do zabawy, jasność wysyłanych komunikatów i sposób okazywania emocji są ważniejsze niż sprawność intelektualna oraz wygląd zewnętrzny. Ze względu na wrodzoną chęć nawiązania kontaktu dzieci z ZD wzbudzały u pozostałych potrzebę pomocy i opiekit. Dla potwierdzenia warto porównać tutaj badania nad funkcjonowaniem dzieci ze spektrum autyzmu, których nieprzewidywalne i niejasne zachowania są często przyczyną niechęci i odrzucania przez rówieśników. Umiejętność współżycia $\mathrm{w}$ grupie łączy się $\mathrm{z}$ rozwojem teorii umysłu, czyli umiejętnością odczytywania czyichś myśli i emocji. Dzieci z ZD mają wysoki poziom empatii, co wpływa dodatnio na budowanie kontaktów w grupie. Należy równocześnie mieć świadomość, że chociaż wiek dojrzałości społecznej posuwa się naprzód, dzieci z ZD nigdy nie osiągną pełnej dojrzałości emocjonalnej (wyrażanie, rozpoznawanie, kontrolowanie emocji). Nasuwa się wniosek, że dzieci z ZD będą lepiej funkcjonować w prostych sytuacjach społecznych. Okoliczności, które będą niezrozumiałe, mogą uruchamiać u nich zachowania trudne ${ }^{5}$. Przykładem zachowań, które można zaobserwować w pracy grup przedszkolnych, są: dekoncentracja, odchodzenie od zabawy w kręgu, rozmawianie, zaczepianie innych dzieci, zajmowanie się częściami garderoby, wokalizacje, znudzenie. Bardzo ważna dla procesu wychowania, kształcenia i terapii jest świadomość na-

${ }^{4}$ B. Bartosik, L. Sadowska, A.M. Choińska, Dojrzałość społeczna dzieci z zespołem Downa rehabilitowanych zgodnie z zasadami Wroctawskiego Modelu Usprawniania w środowisku rodzinnym [w:] Zespót Downa - postępy w leczeniu, rehabilitacji i edukacji, red. J. Patkiewicz, Polskie Towarzystwo Walki z Kalectwem, Wrocław 2008, s. 106-107.

${ }^{5}$ Ibidem, s. 108. 
uczyciela, że zachowania te nie są przejawem złej woli dziecka, ale ograniczonymi możliwościami w obszarze poznawczym. Trudne zachowanie dziecka nie jest uderzeniem w osobę nauczyciela, ale jego wołaniem o dostosowanie metod, form i środków pracy do jego potrzeb.

Dzieciom, poza trudnościami motorycznymi i w zakresie komunikacji werbalnej, towarzyszą także deficyty sensoryczne (wzrokowe i słuchowe). Poza tym (i przede wszystkim) słabiej rozwinięte są procesy psychiczne; występują trudności w krótkotrwałej pamięci słuchowej, krótsza koncentracja uwagi, opóźnienia poznawcze, trudności w generalizowaniu, powiązaniu wiedzy z wcześniej nabytą oraz jej przechowywaniu i rozumieniu.

W związku z powyższym Alina Smyczek ${ }^{6}$, specjalistka w dziedzinie komunikacji alternatywnej i wspomagającej, proponuje, by aranżować sytuacje wielozmysłowego poznawania. Wielomodalność przekazu polega na tym, że komunikacja słowna (dominująca w edukacji metoda nauczania) będzie wzmacniana komunikatem niewerbalnym (spojrzeniem, gestem wskazywania miejsc lub osób, przedmiotem, znakiem manualnym lub graficznym). Należy angażować różne układy percepcyjne, co:

- poprawia rozumienie (komunikacja receptywna) - słowo + bodziec wzrokowy + ruch (gest) podnoszą szansę zrozumienia sytuacji i kierowanego do dziecka komunikatu; eksponowanie przedmiotu/znaku graficznego i/lub znaku manualnego + wypowiadanie słowa uczy dziecko sposobów reprezentowania (oznaczania) elementów rzeczywistości;

- stwarza warunki ekspresji (komunikacja ekspresywna) - budowany jest nowy kod do komunikowania - znaki przestrzenno-dotykowe, manualne, graficzne są dla dziecka łatwiejsze w użyciu; dorosły modeluje potencjalne zachowania

${ }^{6}$ A. Smyczek, Zastosowanie wspomagajacych $i$ alternatywnych metod komunikacji (AAC approach) w terapii matych dzieci zagrożonych poważnymi zaburzeniami w porozumiewaniu się [w:] Alternatywne i wspomagajace metody komunikacji, red. J.J. Błeszyński, Oficyna Wydawnicza „Impuls”, Kraków 2006, s. 79. 
komunikacyjne dziecka; wzrasta repertuar, skuteczność i szybkość przekazywania komunikatów przez dziecko w warunkach bezpiecznych - nie jest ono narażone na bycie niezrozumianym przez osoby $z$ otoczenia.

Dzieci z ZD nabywają nowe umiejętności poprzez uczenie oparte na wykorzystaniu kanału wzrokowego oraz zdolność do uczenia się za pomocą gestów i znaków wizualnych, np. obrazków ${ }^{7}$. Prowadzi to do wniosku, że wspomaganie rozwoju tychże dzieci możliwe jest poprzez zastosowanie odpowiednich metod pracy (dostosowanych do specyfiki rozwoju i indywidualnych możliwości, a nie stosowanych np. ze względu na powszechnie uznaną efektywność).

Odpowiednia metoda stanowi szansę, by dzieci rozwinęły dostępne im sposoby komunikowania. Jest to ważne ze względu na drugi konstytutywny warunek rozwoju dzieci z ZD w grupie, jakim jest dialog (nawet bez słów) oparty na więziach między dziećmi i osobami znaczącymi. Osobami znaczącymi mogą być rówieśnicy z ZD, pełnosprawni rówieśnicy oraz nauczyciele czy terapeuci. Bycie w komunikacji, w relacji powoduje, że człowiek czuje się akceptowany, ważny, szanowany przez kogoś, ale też potrzebny komuś.

Odrzucenie, odłączenie, wykluczenie jest bolesne, gdyż wypadamy z kręgu, w którym panował obowiązek troszczenia się o siebie nawzajem, ponoszenia odpowiedzialności jeden za drugiego, spieszenia z wzajemną pomocą. Oznacza to znalezienie się na od-ludziu, w miejscu bez-troski ${ }^{8}$.

\section{Metodologia badań}

Jako pedagog specjalny w przedszkolnej grupie integracyjnej obserwowałam dzieci z ZD z punktu widzenia ich zaburzonego

7 A. Żyta, Życie z zespołem Downa. Narracja biograficzne rodziców, rodzeństwa i dorostych osób z zespołem Downa, Oficyna Wydawnicza „Impuls”, Kraków 2011, s. 38.

${ }^{8}$ J. Mizińska, Troska o Innego - potrzeba bycia potrzebnym, [w:] Troska o Innego. Szkice humanistyczne, red. J. Sośnicka, J. Dobrołowicz, Kieleckie Towarzystwo Naukowe, Instytut Pedagogiki i Psychologii Uniwersytetu Jana Kochanowskiego, Kielce 2011, s. 13. 
rozwoju i wynikających $\mathrm{z}$ tego trudności w realizacji oczekiwań ku nim kierowanych, a jednocześnie widziałam dziecko wśród innych dzieci, które dąży do relacji i buduje je w specyficzny sposób. Ważne zatem było, aby drogą badań (obserwacji, analiz zachowań) dostrzec mechanizmy społeczne i tendencje, jakie pojawiają się w funkcjonowaniu owych dzieci, oraz znaleźć sposób, by wesprzeć rozwój psychospołeczny dzieci z ZD.

Diagnoza rozwoju psychospołecznego dzieci odbyła się też na podstawie analizy dokumentacji, tj.:

- orzeczenia poradni psychologiczno-pedagogicznej o potrzebie kształcenia specjalnego,

- indywidualnego programu edukacyjno-terapeutycznego sporządzonego dla każdego dziecka z roku 2010/2011 poprzedzającego rok przeprowadzenia postępowania eksperymentalnego,

- dziennika zajęć rewalidacyjno-wychowawczych prowadzonych przez pedagoga,

- sporządzonego w postaci socjogramów zeszytu obserwacji zachowań dzieci z ZD w sytuacjach zabawy swobodnej, zabawy kierowanej i zajęć zorganizowanych z roku 2010/2011,

- rozmów przeprowadzonych z rodzicami, nauczycielkami i pedagogami zajmującymi się dzieckiem.

Narzędziami do diagnozy rozwoju psychospołecznego były P-PAC i PAC-1 H. C. Gunzburga. PAC z ang. Progress Assesment Chart - ocena postępu w rozwoju społecznym ${ }^{9}$.

Dodatkowo każde dziecko przed realizacją eksperymentalnego projektu oddziaływań dydaktyczno-terapeutycznych miało wykonany „Profil efektywności porozumiewania się” Magdaleny Grycman $^{10}$. Autorka narzędzia zaproponowała, aby na ocenę efektywności komunikowania dzieci złożyły się umiejętność przekazywania informacji, budowanie wypowiedzi, funkcjonalne współgranie z roz-

${ }^{9}$ T. Witkowski, Metody PAC i PAS w społecznej rewalidacji upośledzonych umysłowo, Centralny Ośrodek Metodyczny Poradnictwa Wychowawczo-Zawodowego Ministerstwa Edukacji Narodowej, Warszawa 1988, s. 3.

${ }^{10}$ M. Grycman, Sprawdź, jak się porozumiewam, Stowarzyszenie Rehabilitacyjne Centrum Rozwoju Porozumiewania, Kraków 2009, s. 6. 
mówcą (interakcja konwersacyjna), ogólne nastawienie i motywacja do komunikacji. Na podstawie tych narzędzi oceniłam umiejętności porozumiewania (komunikowanie to sfera najsłabiej rozwinięta i zakłócająca funkcjonowanie dzieci w grupie). Następnie stworzyłam projekt zadań i zabaw interakcyjnych rozwijających umiejętności komunikacyjne. Projekt oddziaływań dydaktyczno-terapeutycznych "Ja mówię" przygotowany był dla pięciorga dzieci z ZD i zróżnicowany był pod kątem potrzeb i możliwości każdego dziecka.

Diagnozując funkcjonalne współgranie z rozmówcą, posłużyłam się poziomami zaproponowanymi przez M. Grycman ${ }^{11}$ :

- Poziom 0 - zupełny brak współgrania przy komunikacji bierność w kontakcie z rozmówcą, możliwe zachowania trudne, np. gryzienie oraz zachowania autostymulacyjne, np. kiwanie się, uderzanie w ścianę.

- Poziom 1 - Prawie zupełny brak współgrania przy komunikacji, jedno zachowanie komunikacyjne z grupy zachowań negujących bądź proszących.

- Poziom 2 - Krótkie momenty współgrania. Druga osoba prowadzi rozmowę, badany wymaga pomocy, aby podtrzymać kontakt, np. prowadzący mówi: „Nie rozumiem, co mówisz. Będę zadawać inne pytania, by dowiedzieć się tego. Czy chodziło ci o wodę?". Jeśli badanemu nie udaje się przekazać swoich myśli, zaobserwować można zachowania wycofujące, np. odwracanie wzroku od partnera komunikacji, obniżenie nastroju.

- Poziom 3 - Wyraźny brak równowagi między rolą mówcy a słuchacza. W rozmowie $\mathrm{z}$ dzieckiem występują drażniące przerwy będące skutkiem nieporozumień. Brak jest równowagi pomiędzy rolami mówcy i słuchacza. Osoba aktywna w dialogu to osoba mówiąca. Ona inicjuje temat rozmowy oraz podtrzymuje konwersację. Podczas rozmowy badany nie wycofuje się z konwersacji, potrafi aktywnie współpracować w poszukiwaniu właściwego zrozumienia komunikatu, który chce

11 Ibidem, s. 16. 
przekazać. Podpowiada słowa, które mają naprowadzić słuchacza na właściwy kierunek rozmowy.

- Poziom 4 - Dosyć dobre współgranie, ale ma trudności z jego podtrzymywaniem. Nie obserwuje się wysiłku związanego z celem, kierunkiem obranej formy rozmowy. Dotyczy ona raczej jednego tematu. Mogą wystąpić niejasności dotyczące struktury związanej z porozumiewaniem się, tj. wyraźnego rozpoczęcia, rozwinięcia i zakończenia, np. badany wyraża na początku potrzebę: „chcę się z tobą bawić”, gdy normą społeczną jest przywitanie się z osobą, którą widzimy po raz pierwszy w ciągu dnia.

- Poziom 5 - Dobre funkcjonalne współgranie. Badany ma dobre poczucie równowagi między rolą mówcy a rolą słuchacza. Przekaz jest jednoznaczny, zgodny z tematem.

$\mathrm{W}$ badaniach własnych zastosowałam metodę quasi-eksperymentu. Model tego eksperymentu nie spełnia wymogu randomizacji stąd quasi-eksperyment (qE). Dobór grup był w moich badaniach celowy. Była to sytuacja, kiedy jako badacz, nie miałam możliwości utworzenia grup kontrolnej i eksperymentalnej poprzez losowy przydział ze wspólnej próby (pracowałam jako pedagog w grupie $\mathrm{z}$ dziećmi z ZD, z góry przydzielonej przez dyrekcję placówki). Znalazłam w miejscu badań istniejącą grupę kontrolną, która wydawała się podobna do grupy eksperymentalnej ( $\mathrm{w}$ metodologii nazywana nierównoważną grupą kontrolną) $)^{12}$. Zaletami planu quasi-eksperymentalnego była możliwość prowadzenia badań w warunkach naturalnych i rzeczywistych. W takim quasi-eksperymentalnym planie jako wady można wskazać brak właściwej kontroli nad alternatywnymi wyjaśnieniami, co wpływa na trudność przy formułowaniu jednoznacznych wniosków. Drugą słabością takiego planu jest niemożność manipulowania zmienną niezależną przez badacza, który wobec tego musi określić kierunek związku przyczynowo-skutkowego jedynie przez wnioskowanie logiczne lub teoretyczne.

12 E. Babbie, Podstawy badań społecznych, tłum. W. Betkiewicz, M. Bucholc, P. Gadomski i in., PWN, Warszawa 2013, s. 400. 


\section{Organizacja i teren badań}

Spośród ponad 100 przedszkoli publicznych i około 30 niepublicznych we Wrocławiu wybrałam do badań w doborze celowym placówki integracyjne. Spośród tych przedszkoli w doborze celowym wybrałam te placówki, które od 2009 r. realizowały założenia edukacji włączającej dla grup z jednorodną niepełnosprawnością i w tych przedszkolach szukałam dzieci z ZD. Warunkiem doboru próby było uczęszczanie dziecka do grupy integracyjnej, w której ma 1-4 rówieśników z tym samym zaburzeniem.

Następnie grupę 15 dzieci z ZD podzieliłam na grupę kontrolną i eksperymentalną. Ten podział był celowy, gdyż jako badacz odgrywałam też rolę pedagoga specjalnego, realizującego program dydaktyczno-terapeutyczny w grupie eksperymentalnej.

W semestrze letnim 2010/2011 sporządziłam dla 9 dzieci z ZD zeszyt obserwacji (w postaci socjogramów), obrazujący funkcjonowanie psychospołeczne dzieci $\mathrm{w}$ grupie rówieśniczej (5 dzieci $\mathrm{z}$ grupy eksperymentalnej, $4 \mathrm{z}$ kontrolnej). Obserwacja prowadzona była $\mathrm{w}$ sytuacjach swobodnej zabawy, zabawy kierowanej i zajęć zorganizowanych pod kątem interakcji z rówieśnikami.

Na etapie zwiadu badawczego okazało się, że komunikaty od strony dzieci pełnosprawnych w kierunku obserwowanych dzieci z ZD są wyjątkowo rzadkie i niespontaniczne. Brak wzajemnego zrozumienia powodował, że nie były one atrakcyjnymi partnerami w zabawie i realizatorami wspólnych zadań. Ponadto wyraźnie było widać, że dzieci miały trudności ze zrozumieniem wymagań i sytuacji aranżowanych przez nauczycieli w przedszkolu, a także fizycznie nie mogły poradzić sobie $\mathrm{z}$ powodu słabszego, w porównaniu z rówieśnikami, rozwoju motorycznego. Obserwacja emocji, jakich doświadczały dzieci, nasuwała porównanie do emocji towarzyszących osobie, której „uciekł” właśnie autobus (pomimo włożenia maksymalnych starań, osoba biegnąca na przystanek, na który właśnie podjechał autobus, jest ograniczona swoją sprawnością; nie ma możliwości przyspieszyć ani zatrzymać kierowcę; emocje towarzyszące, gdy autobus odjeżdża to złość, żal, frustracja, przygnębienie, wyco- 
fanie). Takie emocje towarzyszyły każdemu dziecku kilkakrotnie w ciągu dnia (np. gdy rówieśnik szybciej ściągnął z półki piłkę i mógł się nią bawić, gdy budował wyższą wieżę, gdy potrafił szybko i bez trudności ubrać się, a potem być chwalony przez nauczyciela).

Postępowanie eksperymentalne (tym samym praca terapeutyczna, prowadzona indywidualnie i zespołowo) trwało od października 2011 r. do czerwca 2012 r. Prowadzona terapia obejmowała stymulację wszystkich sfer rozwoju ze szczególnym uwzględnieniem obszaru komunikowania się. Porozumiewaniu werbalnemu towarzyszyły elementy metod komunikacji alternatywnej i wspomagającej: w głównej mierze naturalne gesty oraz znaki zaczerpnięte z systemu GuK - Gebarden unterstutze Komunikation - komunikacja wspierana gestami ${ }^{13}$ ), przedmioty, symbole przedmiotowe dotykowe, zdjęcia, wybrane obrazki PCS, piktogramy.

Po dziewięciu miesiącach terapii został dokonany pomiar koncowy poziomu rozwoju psychospołecznego każdego dziecka za pomocą narzędzia PPAC/PAC-1 oraz profilu do oceny umiejętności porozumiewania się M. Grycman (jak w pomiarze początkowym). Przygotowane zostały indywidualne opisy funkcjonowania dzieci. Zestawiono także $\mathrm{w}$ formie tabelarycznej pretest i postest wyników osiągniętych $\mathrm{w}$ poszczególnych obszarach: obsługiwanie siebie, komunikowanie, uspołecznienie, udział w zajęciach.

Takie postępowanie pozwoliło między innymi zbadać rolę komunikacji alternatywnej i wspomagającej dla rozwoju funkcjonalnego współgrania z rozmówcą (ze względu na bardzo szeroki zakres badań przedstawię część wyników badań, które dotyczą tematu tekstu). Szukałam odpowiedzi na pytanie: czy i w jakim zakresie można nauczyć dziecko z ZD umiejętności komunikowania się (odbierania i nadawania) przy zastosowaniu indywidualnych programów terapeutycznych budowanych na metodach komunikacji alternatywnej i wspomagającej?

${ }^{13}$ Metoda z zakresu Komunikacji Alternatywnej i Wspomagającej, oparta na gestach i obrazkach; stworzona przez prof. Ettę Wilken, która początkowo pracowała z dziećmi z niedosłuchem, a potem z dziećmi z zespołem Downa. 


\section{Analiza i interpretacja wyników badań}

Aleksandra Maciarz ${ }^{14}$ podkreślała, że opanowanie różnych rodzajów umiejętności społecznych uwarunkowane jest ukształtowaniem się u dzieci dyspozycji motoryczno-sprawnościowych, emocjonalno-motywacyjnych i intelektualnych. W związku z tym, że wszystkim dzieciom z ZD towarzyszyły deficyty lub opóźnienia w wyżej wymienionych dyspozycjach, ważne było wspomaganie tych obszarów tak, by ułatwić im funkcjonowanie w obrębie grupy rówieśniczej.

Obserwacja uczestnicząca i realizacja badań w grupie, gdzie obok pełnosprawnych dzieci (15) funkcjonowały dzieci z jednorodnym zaburzeniem (tutaj pięcioro dzieci z ZD) pokazały, że może być to kluczowe rozwiązanie dla wspomagania rozwoju społecznego dzieci z trudnościami rozwojowymi. W obrębie grupy, która prezentowała wzorce prawidłowych społecznych zachowan, zaczęła funkcjonować grupa dzieci z ZD. Codzienne doświadczanie interakcji pomiędzy dziećmi z ZD doprowadziło do wniosku, że poza rozwojem społecznym dzieci mają szansę na szczęśliwy rozwój osobisty.

Obserwacja wskazała, że źródłem tego poczucia szczęścia, bezpieczeństwa, radości i satysfakcji z kontaktów wśród dzieci z ZD jest przekonanie o wzajemnym podobieństwie. Dzieci z ZD zauważają, że są do siebie nawzajem podobne $\mathrm{w}$ wielu wymiarach: dostrzegają u siebie podobieństwo, podobieństwo zachowań (np. upór, przytulanie) i naśladowały te zachowania, często bezkrytycznie. Przyczyną poczucia wspólnoty ze sobą mogły być również doświadczenia wynikające $\mathrm{z}$ takiego samego lub podobnego traktowania przez nauczycieli i specjalistów (przy wspólnych zabawach czy zajęciach zwykle były łączone; często same tego oczekiwały bądź stawiane były im takie same/podobne wymagania). Dzieci z ZD dokonywały również kategoryzacji. Większa część obserwo-

${ }^{14}$ A. Maciarz, Rewalidacja społeczna dzieci, Wyższa Szkoła Pedagogiczna, Zielona Góra 1981, s. 23. 
wanych dzieci podczas zabaw swobodnych jako partnerów wybierała dzieci z tą samą niepełnosprawnością. W czasie zajęć zorganizowanych, przy stolikach lub na dywanie, wybierały miejsca blisko siebie (nawet kiedy zostały im przyporządkowane miejsca $\mathrm{z}$ dala od siebie, po chwili się przesiadały).

Wskazuje to na bliską i ważną więź między dziećmi. Więź jest fundamentem tworzenia się przyjaźni. Posiadanie przyjaciela powoduje, że dziecko ma lepsze zdanie na swój temat, czuje się lubiane i doceniane, ma lepszy dostęp do zabawy, a jest to przecież podstawowa forma aktywności dziecka. W badaniach prowadzonych przez Judy Dunn, czteroletni przyjaciele okazali się również podobni do siebie $\mathrm{w}$ zakresie poziomu rozumienia myśli i uczuć innych ludzi, w swoich zdolnościach werbalnych i pod względem ogólnej inteligencji ${ }^{15}$.

Wspomagające i alternatywne metody komunikacji (AAC) ułatwiały dzieciom porozumiewanie się z najbliższym otoczeniem. Jednakże przez najbliższe otoczenie nie należy rozumieć bliskiego proksemicznie, ale bliskie ze względu na więzi, zaufanie, jakim dzieciom obdarzały wybrane osoby. Rozwój umiejętności komunikacyjnych rozwinął się $\mathrm{w}$ interakcjach między dziećmi z ZD oraz między dziećmi a dorosłymi (pedagog i inni terapeuci).

Komunikacja alternatywna i wspomagająca towarzyszyła dzieciom w naturalnych sytuacjach, była drogą do celu, a nie celem samym w sobie. Doskonalenie poznanych gestów, obrazków odbywało się również w gabinecie w formach zabawy, a nie instruktażowego wykonywania poleceń. W chwili rozpoczynania terapii dzieci porozumiewały się dostępnym im sposobem, dlatego wybór systemu znaków uwzględniał ich umiejętności komunikacyjne.

Poprzez zaproponowane oddziaływania zrealizowany został podstawowy kierunek rozwoju społecznego. Dzieci dzięki wykorzystywaniu gestów, obrazków, wokalizacji osiągały coraz większą zaradność, pewność siebie, niezależność, opanowanie, gotowość do

15 J. Dunn, Przyjaźnie dzieci, Wydawnictwo Uniwersytetu Jagiellońskiego, Kraków 2008, s. 53. 
podejmowania zadań. Efektem tego stały się nowe sposoby zachowania (akceptowane społecznie), nowe zainteresowania, poszerzenie kręgu przyjaciól, umiejętność wchodzenia w interakcje społeczne uwarunkowane gotowością do porozumiewania się werbalnego lub niewerbalnego.

Jednostka społeczna to taka, która przebywa z innymi, ale także działa z nimi. Badania doprowadziły do konkluzji, że dzieci z ZD są w stanie przystosować się do życia codziennego w różnym stopniu. W głównej mierze decyduje o tym stopień zaburzeń w rozwoju. Drugim czynnikiem jest otoczenie, które powinno szukać miejsca spotkania, dialogu poza tym zaburzeniem. U dzieci, którym zaproponowano pomoc $\mathrm{w}$ postaci AAC, można było zauważyć postęp w obszarze umiejętności komunikowania się. U każdego dziecka zasięg udoskonalenia tego obszaru po roku pracy był inny.

Paulina ${ }^{16}$ na początku w głównej mierze posługiwała się wokalizacjami, komunikowała wyraźnie "tak" /"nie". Po dziewięciu miesiącach dominującą formą porozumiewania się u dziewczynki stały się gesty; pokazywała wiele przedmiotów codziennego użytku i aktywności: lala, ryba, chleb, jogurt, kot, pies, banan, jabłko, auto, pociąg, jeść, spać, pić, ubierać się, grać na komputerze (z intencją, że potrzebuje tego przedmiotu lub aktywności), używała prostych słów - mama, tata, Mata - Marta (siostra), Basia (opiekunka), Aga (pedagog).

Mateusz komunikował się głównie za pomocą mimiki i pojedynczych słów, gesty traktował jako zabawę, nie przeniósł w życie ich funkcji. Zwykle bez intencji naśladował je za innymi dziećmi. Wydawało się, że chciał przez to osiągnąć bliskość z nimi. Decyzją rodziców po zakończeniu roku szkolnego kontynuował naukę w szkole specjalnej.

Kuba - od wokalizacji, gestów przeszedł w rozwoju drogę do porozumiewania za pomocą zdań prostych, składających się z 3-4 słów, np. „Karol idzie na basen”, „Aga, nie idź do domu”.

Adrian po roku systematycznych ćwiczeń komunikował się za pomocą gestów, czynił to tak szybko, że często trudno było nadążyć

16 Imiona dzieci zostały zmienione. 
za biegiem opowiadanych zdarzeń. Opowiadał całe historie, co świadczyło o jego bystrości umysłu i rozwijającym się myśleniu przyczynowo-skutkowym, odgrywał sceny z bajek, np. grał gestami Zygzaka McQueena, który szybko się przemieszcza, nagle się zatrzymuje, bo wjechał na gwóźdź, Adaś wyciągał lewarek, podnosił auto, zmieniał oponę, wycierał brudne ręce o spodnie, potem pot z czoła, siadał do auta, machał do mnie na pożegnanie i jechał dalej.

Wiktoria - dużo wokalizowała i gestykulowała, zaczęły pojawiać się słowa w postaci elizji - mama, tata, Róża (siostra), "Aa” (Aga - pedagog), „Aś” (Adaś), „Ol” (Karol). Oczekiwała, podobnie jak Adaś, by komentować jej język.

W sytuacji, gdy nieprawidłowo interpretowałam gest lub wokalizację, dzieci mówiły „nie” lub kiwały przecząco głową/palcem i powtarzały gest wolniej i dokładniej. Można tu użyć porównania do sytuacji, gdy obcokrajowiec trafia do kraju, którego języka nie zna i ma za zadanie dopytać o drogę. Chociaż tubylec będzie tłumaczył i powtarzał komunikat wolno, głośno, pilnując nawet kontaktu wzrokowego, to nie spowoduje to zrozumienia komunikatu, bo jest on ciągle w nieznanym języku. Tymczasem wystarczy zmiana kodu z werbalnego na np. gest lub mapę narysowaną na kartce, by móc się zrozumieć.

Obserwacja dzieci (przez kolejne cztery lata byłam pedagogiem specjalnym w placówce, do której uczęszczały dzieci biorące udział $\mathrm{w}$ procedurze eksperymentalnej) doprowadziła mnie do wniosku, że znaki manualne w pozytywny sposób wpływają na naukę mówienia. U wszystkich dzieci pojawiła się komunikacja werbalna, w mniejszym bądź większym stopniu.

Nauka znaków manualnych, graficznych i przestrzenno-dotykowych często rozpoczyna się zbyt późno. Główną przyczyną może być lęk, że uczenie dziecka komunikacji alternatywnej może hamować u niego rozwój mowy. Tymczasem mowa i alternatywne formy komunikacji nie wykluczają się wzajemnie.

Efektywne porozumiewanie się dziecka jest dla niego dużym osiągnięciem osobistym, wywołującym radość sprawczą i potrzebę doskonalenia kontaktu z najbliższymi. 
Cechą charakterystyczną zachowania dzieci, które miały możliwość kompensowania komunikacji werbalnej za pomocą gestów czy obrazków, stały się harmonia, spokój. Dzieci chętniej podejmowały próby powtórnego komunikowania, kiedy były niezrozumiane, poszukiwały innych dróg, bo miały świadomość, że otoczenie chce zrozumieć, co chcą przekazać. Takie zachowania łagodności, pogody ducha, nielękliwego podejmowania wyzwań przenosiły się na zachowania społeczne. Zmniejszeniu uległa liczba ugryzień, popychania wśród dzieci z ZD (była to często linia samoobrony, gdy pełnosprawny rówieśnik był silniejszy motorycznie i werbalnie w konflikcie np. o zabawkę). Dzieci z ZD potrafiły podejść do pedagoga/nauczyciela i wskazać, kto je skrzywdził, a wręcz odegrać scenkę, w której zostały skrzywdzone.

Dzięki tablicom tematycznym można było z dziećmi prowadzić dialog, w którym to one decydowały o jego przebiegu.

Dzieci nie komunikowały się ze wszystkimi za pomocą gestów, obrazków. Świadomie wybierały osoby, z którymi chciały rozmawiać. Najczęściej byli to rówieśnicy z ZD, pełnosprawni rówieśnicy o łagodnym i opiekuńczym charakterze lub dorośli. Dzieci wiedziały, kto chce i potrafi z nimi współbrzmieć, porozumieć się. Często również właśnie te osoby włączane były do zabawy organizowanej przez dzieci z ZD. Można powiedzieć, że wytworzyła się pewna kultura zabawy tych dzieci. Dominowały w niej proste, jasne zasady, które można było wytłumaczyć za pomocą gestów. Tutaj widać było największe zastosowanie gestów poznanych przez komunikację wspomagającą. Zasady zabawy można było zrozumieć również po przygotowanych pomocach, np. zabawa tematyczna urodziny: dzieci przygotowywały stolik, nakrycia, rysowały tort na kartce, udawały, że grają na gitarze "Sto lat" (pedagog, gdy świętowane były w grupie urodziny, grał zwykle na gitarze "Sto lat" - dzieci bardzo dokładnie odtwarzały tę scenę $\mathrm{w}$ zabawie).

Inną formą były scenki teatralne, gdzie odgrywały sytuacje, które kiedyś widziały (z bajek, filmów, innych teatrzyków) albo wykorzystywały do tego kukiełki. I mimo że nie było tu kwestii werbalnych, dzieci starały się jak najwierniej za pomocą mimiki, wokalizacji, 
proksemiki i gestów przekazać treść spektaklu. Angażowały w to wiele emocji i potrafiły zagrać emocje bohaterów przedstawienia (uczyły się przez to je wyrażać). Przygotowywały również widownię i zapraszały gestami do oglądania, a potem oklaskiwania.

W sytuacjach zadaniowych, dzięki gestom i obrazkom, można było na dłużej utrzymać koncentrację dzieci. Było to wynikiem tego, że lepiej rozumiały zadanie. Chociaż często nie potrafiły samodzielnie doprowadzić go do końca, przy podtrzymywaniu uwagi i dzięki instrukcjom wizualnym było im łatwiej. Ponadto ważne było dawanie dziecku więcej czasu na zrozumienie usłyszanych informacji i przygotowanie odpowiedzi, co wynikało z opóźnionego czasu reakcji, charakterystycznego dla dzieci z ZD.

\section{Podsumowanie i wnioski}

Podsumowując, specyfika rozwoju neurologicznego dzieci z ZD wpływa na ich uczenie się. Jednak wiedza o niej nauczycieli i rodziców zobowiązuje do poszukiwania metod, dzięki którym dziecko będzie efektywniej przyswajało podawany materiał i umiejętności. To właśnie określenie specyficznych cech rozwoju, czyli indywidualnego profilu słabych i mocnych stron dziecka, nadaje kierunek pracy.

Dzieci z ZD, tak jak każde inne, w bardziej lub mniej czytelny dla otoczenia sposób dążą do kontaktu z drugim człowiekiem, zwłaszcza z rówieśnikami. Próbują one nawiązywać kontakt z różnych przyczyn, np. ze względów towarzyskich, powodowane chęcią przekazania tego, co myślą i odczuwają w danym momencie, uzyskania ważnej dla siebie informacji, przekazania żądania lub zapewnienia innym pomocy. Potrzebę nawiązania takiego kontaktu wyzwala często sama sytuacja sprzyjająca porozumiewaniu się, chociażby za pośrednictwem zabawy. Umiejętność przekazywania i odbioru językowo-słownych, prawidłowo zbudowanych komunikatów będących jedną z istotnych dla człowieka cech, jest niekiedy $\mathrm{w}$ niewielkim stopniu dostępna osobom $\mathrm{z} Z \mathrm{ZD}$. W istocie jednak z tym problemem radzą sobie dobrze. W sytuacji komunikacyjnej uciekają się do dostępnych im środków wspomagających porozu- 
miewanie się z otoczeniem, a więc do różnego rodzaju gestów, mimiki, ważnych dla odbiorcy znaków proksemicznych. Przekaz informacji odbywa się nie tylko drogą językową, ale także pozajęzykową (komunikacja niejęzykowa). Sygnały niejęzykowe mogą być przekazywane i przyjmowane kanałem oralno-audytywnym (czyli ustno-słuchowym), oralno-audytywno-kinezycznym (czyli ustno-słuchowo-ruchowym) lub kinetyczno-optyczno-uczuciowym (czyli ruchowo-wzrokowo-czuciowym), co wielu osobom, zwłaszcza dzieciom z ZD, ułatwia nawiązywanie kontaktu z otoczeniem ${ }^{17}$.

Podsumowując, fundamentalnym zadaniem dla organizatorów wychowania przedszkolnego jest budowanie takich warunków, gdzie dzieci z niepełnosprawnością będą miały obok siebie rówieśników podobnych do siebie (pod różnym względem). Przekonanie o wzajemnym podobieństwie zbliża do siebie, chroni przed samotnością. Grupy z homogenicznym zaburzeniem są niewątpliwie rozwiązaniem właśnie w tym kierunku. Dzieje się tak dlatego, że dają możliwość identyfikacji z kimś, kto ma podobne możliwości i ograniczenia, co w efekcie buduje poczucie bezpieczeństwa. To bezpieczeństwo jest fundamentem tworzenia więzi warunkującej rozwój człowieka we wszystkich jego płaszczyznach. Tworzenie więzi również przez wielomodalne komunikowanie $\mathrm{z}$ dzieckiem wpływa na jego szczęśliwe funkcjonowanie w otoczeniu. Osoba, która chce się z tym dzieckiem kontaktować (nauczyciel, rówieśnik), poszukuje dróg porozumienia i sprawia przez to, że czuje się ono w pełni akceptowane i przyjęte takim, jakie jest.

\section{Bibliografia}

Babbie E., Podstawy badań społecznych, tłum. W. Betkiewicz, M. Bucholc, P. Gadomski i in., PWN, Warszawa 2013.

${ }_{17}$ E.M. Minczakiewicz, J.J. Błeszyński, Niepetnosprawność intelektualna jako zaburzenie wspótwystępujące, [w:] Diagnoza i terapia logopedyczna osób z niepetnosprawnościa intelektualna, red. J.J. Błeszyński, K. Kaczorowska-Bray, Wydawnictwo Harmonia, Gdańsk 2012, s. 79-80. 
Bartosik B., Sadowska L., Choińska A.M., Dojrzałość społeczna dzieci z zespołem Downa rehabilitowanych zgodnie z zasadami Wroctawskiego Modelu Usprawniania w środowisku rodzinnym [w:] Zespół Downa - postępy w leczeniu, rehabilitacji i edukacji, red. J. Patkiewicz, Polskie Towarzystwo Walki z Kalectwem, Wrocław 2008.

Dunn J., Przyjaźnie dzieci, Wydawnictwo Uniwersytetu Jagiellońskiego, Kraków 2008.

Grycman M., Sprawdź, jak się porozumiewam, Stowarzyszenie Rehabilitacyjne Centrum Rozwoju Porozumiewania, Kraków 2009.

Jędrzejowska A., Wspomaganie rozwoju społecznego dziecka z zespołem Downa w przedszkolnej grupie rówieśniczej, Oficyna Wydawnicza Atut - Wrocławskie Wydawnictwa Oświatowe, Wrocław 2017.

Maciarz A., Rewalidacja społeczna dzieci, Wyższa Szkoła Pedagogiczna, Zielona Góra 1981.

Minczakiewicz E.M., Błeszyński J.J., Niepetnosprawność intelektualna jako zaburzenie wspótwystęujace, [w:] Diagnoza i terapia logopedyczna osób z niepetnosprawnościa intelektualna, red. J.J. Błeszyński, K. Kaczorowska-Bray, Wydawnictwo Harmonia, Gdańsk 2012.

Mizińska J., Troska o Innego - potrzeba bycia potrzebnym, [w:] Troska o Innego. Szkice humanistyczne, red. J. Sośnicka, J. Dobrołowicz, Kieleckie Towarzystwo Naukowe, Instytut Pedagogiki i Psychologii Uniwersytetu Jana Kochanowskiego, Kielce 2011.

Okoń W., Nowy stownik pedagogiczny, Żak Wydawnictwo Akademickie, Warszawa 1998.

Skórczyńska M., Wspomaganie rozwoju dziecka z zespołem Downa w wieku przedszkolnym, [w:] Wczesna interwencja i wspomaganie rozwoju małego dziecka, red. B. Cytowska, B. Winczura, Oficyna Wydawnicza „Impuls”, Kraków 2008.

Smyczek A., Zastosowanie wspomagajacych $i$ alternatywnych metod komunikacji (AAC approach) w terapii małych dzieci zagrożonych poważnymi zaburzeniami w porozumiewaniu sie, [w:] Alternatywne i wspomagajace metody komunikacji, red. J.J. Błeszyński, Oficyna Wydawnicza „Impuls”, Kraków 2006.

Trybuś M., Rola komunikacji niewerbalnej w relacji nauczyciel - dziecko, [w:] Rozwój daje radość. Terapia dzieci upośledzonych umysłowo w stopniu głębokim, red. J. Kielin, Gdańskie Wydawnictwo Psychologiczne, Gdańsk 1999.

Witkowski T., Metody PAC i PAS w społecznej rewalidacji upośledzonych umystowo, Centralny Ośrodek Metodyczny Poradnictwa Wychowawczo-Zawodowego Ministerstwa Edukacji Narodowej, Warszawa 1988.

Żyta A., Życie z zespotem Downa. Narracja biograficzne rodziców, rodzeństwa i dorostych osób z zespotem Downa, Oficyna Wydawnicza „Impuls”, Kraków 2011. 